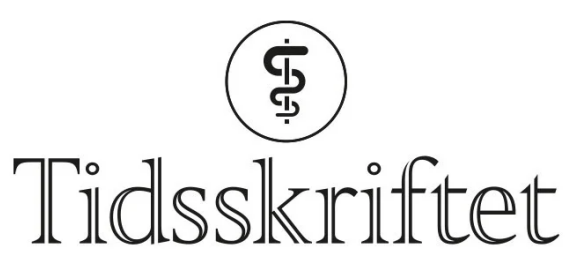

DEN NORSKE LEGEFORENING

\title{
En kvinne i 50-årene med magesmerter og alvorlig laktacidose
}

NOE A LARE AV

\section{ANN-ELIN MELING STOKLAND}

ann-elin.meling.stokland@sus.no

Mottaksklinikken

Stavanger universitetssjukehus

Ann-Elin Meling Stokland er lege i spesialisering i indremedisin og i endokrinologi.

Forfatteren har fylt ut ICMJE-skjemaet og oppgir ingen interessekonflikter.

\section{IDA KLOSTER}

Medisinsk avdeling

Haugesund sjukehus

Ida Kloster er lege i spesialisering i indremedisin og endokrinologi og er konstituert overlege.

Forfatteren har fylt ut ICMJE-skjemaet og oppgir ingen interessekonflikter.

\section{BJØRN EGIL VIKSE}

Universitetet i Bergen

og

Medisinsk avdeling

Haugesund sjukehus

Bjørn Egil Vikse er dr.med., spesialist i indremedisin og i nyresykdommer, professor og klinikkoverlege.

Forfatteren har fylt ut ICMJE-skjemaet og oppgir ingen interessekonflikter.

\section{ARNE SKJOLD}

Radiologisk avdeling

Haugesund sjukehus

Arne Skjold er ph.d., spesialist i radiologi og overlege.

Forfatteren har fylt ut ICMJE-skjemaet og oppgir ingen interessekonflikter.

\section{RENATE VIK}

Avdeling for bryst- og endokrinkirurgi

Haukeland universitetssjukehus

Renate Vik er spesialist i generell kirurgi og i bryst- og endokrinkirurgi og er overlege.

Forfatteren har fylt ut ICMJE-skjemaet og oppgir ingen interessekonflikter.

\section{BJ $\varnothing R N$ GUNNAR NEDREB $\varnothing$}

Universitetet i Bergen

og

Medisinsk avdeling 


\section{En kvinne i 50-årene ble innlagt med akutte magesmerter, hypoksi og alvorlig laktacidose. I forløpet utviklet hun rabdomyolyse, akutt nyresvikt og transaminasestigning. Den komplekse sammensetningen av organmanifestasjoner viste seg etter hvert å ha en svært uventet årsak.}

En tidligere frisk kvinne i 5o-årene ble lagt inn på kirurgisk avdeling på sitt lokalsykehus med magesmerter og dyspné. Prehospitalt var $\mathrm{SaO}_{2}$ målt til $80 \%$. På sykehuset ble hun tatt imot av et medisinsk akutteam. Hun hadde blodtrykk på 121/57 mm Hg, sinustakykardi med frekvens 120-140 slag per minutt, respirasjonsfrekvens 4o, temperatur $36,0{ }^{\circ} \mathrm{Cog}$ metning $96 \%$ med $15 \mathrm{~L}_{2}$ på maske. Hun var uklar, men våken. Huden var marmorert, og hun var diffust trykkøm i buken, men det var ikke mistanke om peritonitt. Det var normale funn ved lungeauskultasjon. Blodgass viste $\mathrm{pH}$ 6,8 (referanseområde 7,35-7,45), $\mathrm{pCO}_{2} 4,8 \mathrm{kPa}(4,7-5,9), \mathrm{pO}_{2} 11,7 \mathrm{kPa}(10,4-13,2)$, bikarbonat $3 \mathrm{mmol} / \mathrm{L}$ (22-26), hemoglobin $12 \mathrm{~g} / \mathrm{dl}$ (11,7-17,0), natrium $150 \mathrm{mmol} / \mathrm{L}$ (137-145), kalium 8,2 mmol/L (3,5-4,5), glukose 8,2 mmol/L (4,0-6,o) og laktat $28 \mathrm{mmol} / \mathrm{L}(0,4-1,8)$. EKG viste sinustakykardi uten andre patologiske funn.

Laktacidose, sinustakykardi og lav oksygenmetning forekommer ved hypovolemisk sjokk, men denne pasienten hadde normalt blodtrykk ved innkomst. Magesmertene gjorde at det var viktig å avklare akutte tilstander i buken som årsak til laktacidosen. I anamnesen var det ikke opplysning om blodig oppkast eller melena. CT abdomen ble rekvirert som øyeblikkelig hjelp for nærmere avklaring.

Kontroll blodgass tatt 30 minutter etter innkomst viste $\mathrm{pH}<6,7$, fall $i$ hemoglobin $(\mathrm{Hb})$ til 9,o g/dL, og laktat $29 \mathrm{mmol} / \mathrm{L}$. Blodprøver viste $\mathrm{Hb} 9,4 \mathrm{~g} / \mathrm{dL}$ (11,7-15,3), trombocytter $233 \times 10^{9} / \mathrm{L}(165-387)$, leukocytter 31,o $\times 10^{9} / \mathrm{L}$ (3,5-11,o), CRP $57 \mathrm{mg} / \mathrm{L}(<5 \mathrm{mg} / \mathrm{L})$, natrium $150 \mathrm{mmol} / \mathrm{L}$ (137-145), kalium 6,4 mmol/L (3,5-5,1), total-kalsium 2,86 mmol/L (2,2-2,55), kreatinin $186 \mu \mathrm{mol} / \mathrm{L}$ (45-9o), pro-BNP $659 \mathrm{ng} / \mathrm{L}$ (<338), alaninaminotransferase (ALAT) $147 \mathrm{U} / \mathrm{L}$ (10-45), gamma-glutamyltranspepsidase (GGT) $65 \mathrm{U} / \mathrm{L}$ (10-75), alkalisk fosfatase (ALP) $79 \mathrm{U} / \mathrm{L}$ (35-105), kreatinkinase (CK) $1665 \mathrm{U} / \mathrm{L}$ (35-210), albumin $27 \mathrm{~g} / \mathrm{L}(36-45)$ og troponin-I $186 \mathrm{ng} / \mathrm{L}(<16)$.

Det ble startet behandling med intravenøs vaske, glukose-insulin-infusjon, buffer (natriumhydrogenkarbonat, $500 \mathrm{ml}$ ) og antibiotika (piperacillin/tazobaktam) intravenøst. Pasienten ble flyttet til intensivavdelingen for stabilisering. I mellomtiden fortalte pasienten om forbruk av ibuprofentabletter, $600 \mathrm{mg}$, minst tre ganger daglig de siste tre ukene før innleggelsen grunnet sterke smerter mellom høyre flanke og skulder. På intensivavdelingen ble pasienten pressorkrevende, og man igangsatte noradrenalininfusjon.

CT tatt én time etter innkomst viste hyperperfusjon i skjelettmuskulaturen, som ble vurdert å vcere betinget $i$ alvorlig acidose (1). Det ble også beskrevet fettvevsinflammasjon og uryddige forhold $i$ pylorusområdet. Funnet kombinert med kliniske tegn ga mistanke om duodenalblødning. Intravenøs bolus med pantoprazol ble gitt, med påfølgende overgang til kontinuerlig infusjon. Pasienten ble gastroskopert samme dag, med funn av prepylorisk gastritt med flere små ulcuser, stort koagel $i$ bulbus, som ga mistanke om duodenitt, og vedvarende sivblødning fra duodenum. Det var kun behov for én SAG-enhet innleggelsesdagen og to nye påfølgende døgn.

Hun ble intubert i forbindelse med gastroskopien, men var etter dette respiratorisk stabil uten ventilasjonsstøtte. Intensivavdelingen beskrev en alvorlig laktacidose med elektrolyttforstyrrelser som ikke sto i forhold til hemodynamisk status og omfanget av den påviste blødningen.

Akutt intoksikasjon med ibuprofen kan gi metabolsk acidose, spesielt laktacidose (므), men hos denne pasienten var det kun opplysning om bruk av terapeutiske doser. 
Pasienten ble stabilisert med ovennevnte behandling, og laktacidosen normaliserte seg seks timer etter innkomst. Vasopressorbehandling ble kun gitt forbigående, og hun fikk i tillegg 5 liter vaske første døgn.

Dag 3 viste blodprøver kreatinin på $200 \mu \mathrm{mol} / \mathrm{L}$ (45-9o), karbamid 18,7 mmol/L (3,1-7,9), stigende CK til $36882 \mathrm{U} / \mathrm{L}$, stigende levertransaminaser med ASAT $9299 \mathrm{U} / \mathrm{L}$ (10-35) og ALAT $7223 \mathrm{U} / \mathrm{L}$ (10-45), bilirubin $13 \mu \mathrm{mol} / \mathrm{L}\left(5^{-25}\right)$ og INR 2,o (o,8-1,1). På dette tidspunktet hadde blodtrykket holdt seg normalt etter seponering av vasopressorbehandling, og pasienten hadde god diurese.

Akutt nyresvikt kunne relateres til bruk av høye doser ibuprofen, kombinert med hypovolemi og rabdomyolyse basert på signifikant CK-stigning. Rabdomyolyse forekommer blant annet ved overanstrengelse av muskulatur, hypotermi, trykkskade/traume, bruk av medikamenter, elektrolyttforstyrrelser eller ved hypoksisk skade, som var antatt årsak i dette tilfellet. Behandling av rabdomyolyse er omdiskutert. I alvorlige tilfeller gis forsert alkalisk diurese, men i dette tilfellet ble det kun gitt væskebehandling.

Pasienten hadde også betydelig forhøyede transaminaser kombinert med INR-stigning. Flere differensialdiagnoser ble vurdert: paracetamolforgiftning, hypovolemisk/iskemisk leverskade og autoimmun, viral eller toksisk hepatitt.

Pasienten hadde negativt paracetamolspeil ved innkomst, og hun avkreftet overforbruk av alkohol. Supplerende blodprøver tatt dag 3 viste normal serologi for hepatitt A, B og C, Epstein-Barr-virus og cytomegalovirus. Det var negativt funn av antinuklecre antistoffer (ANA). Transaminasestigning kan ses ved rabdomyloyse, men transaminasene var høyere enn det man ville ha forventet hvis dette var årsaken isolert sett (3).

Pasientens tilstand bedret seg i løpet av noen få dager med normalisert nyrefunksjon, CK, transaminaser, elektrolytter og blodgasser. På CT-bildene tatt ved innkomst ble det som bifunn beskrevet en tumor i høyre binyre, som ikke ble vektlagt $i$ den initiale vurderingen. Binyretumoren hadde heterogen tetthet, som kunne gi radiologisk mistanke om feokromocytom (figur 1). Dag 4 ble det målt metanefriner i plasma, og CT av binyrer uten kontrast bekreftet en tumor på $35 \times 36 \times$ $40 \mathrm{~mm}$, med en tetthet på 15 - 30 HU og uten typisk adenomutseende.

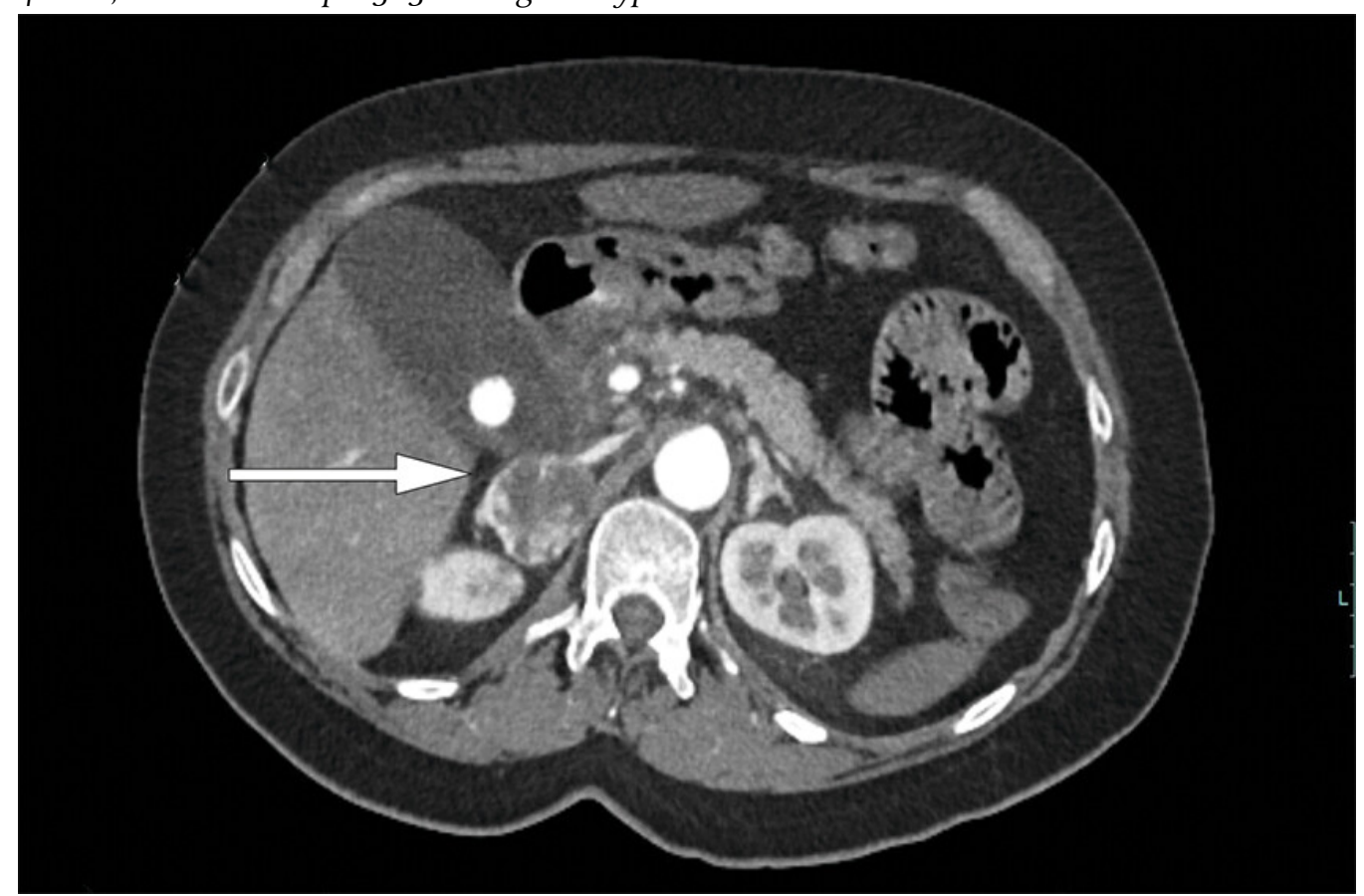

Figur 1 CT-bilde som viser binyretumor.

Pasienten ble overført til medisinsk avdeling samme dag for videre utredning. Like etter overflytting ble pasienten på nytt hemodynamisk ustabil, med hemoglobinfall fra $11 \mathrm{~g} / \mathrm{dL}$ til $8 \mathrm{~g} / \mathrm{dL}$ i løpet av noen timer. Reblødning med sjokkutvikling ble mistenkt. Denne gangen ble hun laparotomert som øyeblikkelig hjelp for bedre visualisering av blødningskilde. Arteriell blødning i duodenum ble bekreftet og behandlet med omstikninger. Selve prosedyren ble beskrevet som ukomplisert, men under operasjonen ble det registrert takykardi med frekvens rundt 110-120 slag/min, antatt å vcere 
sjokkbetinget. Det ble dokumentert kortvarig blodtrykksfall til 78/45 mm Hg. Hun ble igjen behandlet med infusjon av vesese og noradrenalin. Sistnevnte kunne seponeres åtte timer etter operasjonen. I det videre forløpet var pasienten stabil. Etter 11 dagers opphold ble hun skrevet ut til hjemmet i god allmenntilstand.

Etter utskrivelse fikk vi svar på første prøve av metanefriner, som ble tatt dag 4 mens pasienten fortsatt lå på intensivavdelingen. Denne viste normetanefrin på 12,56 $\mathrm{nmol} / \mathrm{L}(<0,89)$ og metanefrin på $0,33 \mathrm{nmol} / \mathrm{l}(<0,45)$. Kontrollprøve under oppholdet (dag 6), i stabil tilstand, viste metanefrin 0,28 $\mathrm{nmol} / \mathrm{L}$ og normetanefrin $8,45 \mathrm{nmol} / \mathrm{L}$, det vil si betydelig forhøyet verdi. En uke etter utskrivelse var normetanefrin vedvarende forhøyet på 9,48 $\mathrm{nmol} / \mathrm{L}$.

Ved poliklinisk vurdering $i$ etterkant av sykehusoppholdet avkreftet pasienten symptomer med anfallsvis varmefølelse, hjertebank eller hodepine. Ved gjennomgang av kurven hennes under oppholdet hadde hun i stabil tilstand tendens til hypertensjon med daglige blodtrykksmålinger rundt 165/100 og lett økt hvilepuls rundt $85 \mathrm{slag} / \mathrm{min}$.

Feokromocytom mistenkes ved binyretumor med høy tetthet (ofte > $30 \mathrm{HU}$ ) og heterogen struktur på CT uten kontrast. Ved kontrastundersøkelse er det typiske for feokromocytomene at de har høy grad av utvasking. Supplerende utredning inkluderer måling av metanefriner (metanefrin, normetanefrin og metoksytyramin) i plasma, som er nedbrytningsprodukter fra adrenalin, noradrenalin og dopamin. Analysen har høy sensitivitet, men lav spesifisitet. Metanefriner analyseres ved hormonlaboratoriene i Bergen, Oslo og Trondheim og prøvesvar foreligger tidligst etter 1-2 uker.

CT-funn og kraftig forhøyede metanefriner ga i dette tilfellet sterk mistanke om feokromocytom. Forløpet som var mer dramatisk enn forventet med alvorlig laktacidose, elektrolyttforstyrrelser og affeksjon av flere organsystemer, kunne ikke forklares av en moderat gastrointestinal blødning alene, men relateres til en «feokromocytomkrise».

Pasienten ble henvist til Avdeling for bryst- og endokrinkirurgi ved regionalt universitetssykehus. Etter to ukers forbehandling med irreversibel alfablokker (fenoksybenzamin) ble binyretumoren fjernet laparoskopisk (figur 2). Histologi bekreftet feokromocytom med frie reseksjonsrender og lav mitotisk aktivitet (Ki-67<5\%). Kontroll seks uker etter operasjonen viste normalisert blodtrykk og normale verdier av normetanefrin. Pasienten ble testet for arvelig form for feokromocytom med genpanel. Ingen av de kjente mutasjonene ble påvist. 


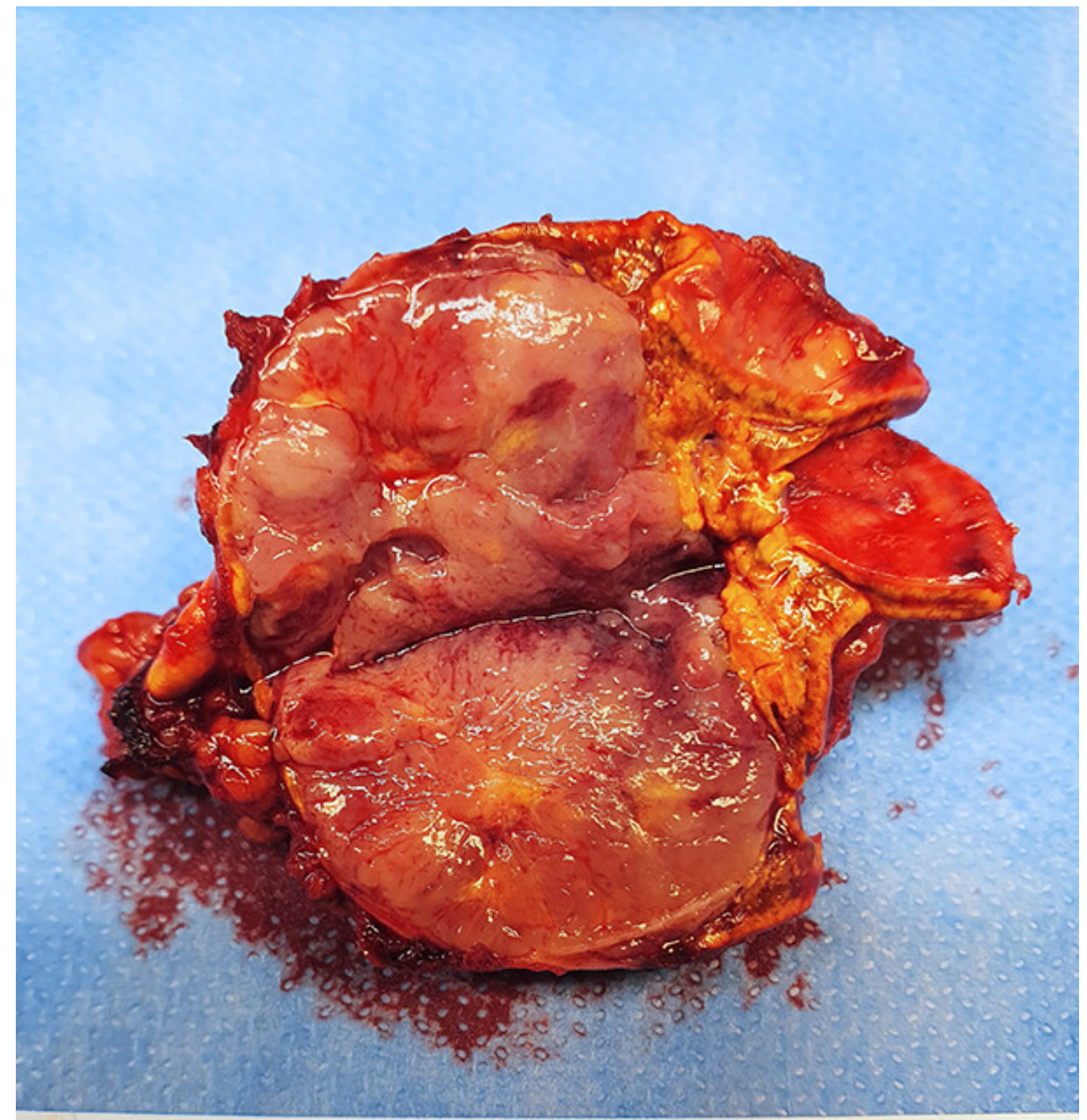

$(97$

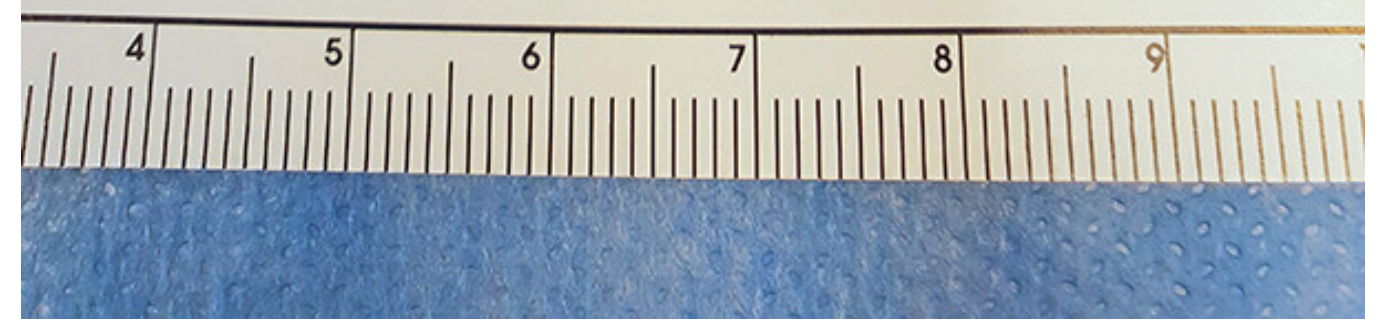

Figur 2 Opererasjonspreparat som viser tumor med omliggende normalt binyrevev.

\section{Diskusjon}

Feokromocytom og paragangliom er tumorer som utgår fra kromaffine celler og som vanligvis produserer en eller flere av katekolaminene adrenalin, noradrenalin eller dopamin (4). De to tumortypene lar seg ikke skille histopatologisk, men har ulik anatomisk plassering. Feokromocytomene er lokalisert til binyremarg eller sjeldnere ekstraadrenalt, mens paragangliomene utgår fra den sympatiske grensestrengen eller fra parasympatiske ganglier på hals. Totalt ligger insidensen på rundt o,6-o,8/100 ooo/år (5).

Feokromocytom kan presentere seg på ulike måter og er et godt eksempel på en medisinsk imitator. Typiske symptomer og kliniske funn forklares av sekresjon av katekolaminer fra tumor. Det er også mulig at tumors plassering og størrelse kan gi lokale kompresjonssymptomer. Klassiske symptomer inkluderer triaden hodepine, hjertebank og 
svette. Også tremor, tungpustethet, generell svakhet og angst kan forekomme. I de fleste tilfeller vil det foreligge hypertensjon, og i en del tilfeller også hyperglykemi grunnet katekolaminindusert insulinresistens.

Feokromocytom kan også presentere seg akutt i form av hemodynamisk ustabilitet med endeorganskade, såkalt feokromocytomkrise. Dette er en lite definert tilstand, men vanligst er hypertensiv krise og katekolaminerg kardiomyopati. Mindre typisk er sjokk og $\mathrm{i}$ ytterste konsekvens multiorgansvikt. I prinsippet kan et hvilket som helst organsystem bli affisert. Vår pasient hadde sannsynligvis kompresjonssymptomer fra tumor, som hun lindret med ibuprofen. Trolig som følge av dette fikk hun duodenalsår med blødning. Den gastrointestinale blødningen førte igjen til et stort og overkompensert utslipp av katekolaminer med påvirkning av sirkulasjon, respirasjon, muskulatur, nyrer og lever.

I litteraturen beskrives pheocromocytoma multisystem crisis som et eget begrep som inkluderer multiorgansvikt, feber, encefalopati og hypotensjon eller hypertensjon (므). Patofysiologisk foreligger det en rask stigning i katekolaminer som gir systemisk effekt og potensielt påvirkning av flere organsystemer (7.). Katekolaminene virker primært på alfareseptorene, som gir vasokonstriksjon med hypertensjon og redusert intravasalt volum. Dette fører igjen til redusert organperfusjon og dermed organsvikt (7.). Feber skyldes samtidig sekresjon av interleukin-6 fra tumor ( $(\underline{8})$. Hypotensjon som manifestasjon er vanskeligere å forklare, men vil nok være avhengig av hvilke katekolaminer tumor produserer. Hypovolemi, redusert perifer respons på katekolaminer, kardial dysfunksjon og dysregulert barorefleksi kan være bidragende faktorer $(\underline{6}, 7.7$.$) .$

Som ved andre kriser i endokrinologien foreligger det ofte en utløsende årsak. Eksempler kan være kirurgi/anestesi, fødsel, traume eller blødning i tumor. Flere medikamenter er også kjent for å kunne utløse forverring eller krise hos pasienter med feokromocytom. Den aktuelle pasienten fikk en patologisk og overkompensert respons på den gastrointestinale blødningen. Responsen på denne, katekolaminerg vasokonstriksjon, bidro til den svært alvorlige laktacidosen, akutt nyresvikt, rabdomyolyse og transaminasestigning. Høye nivåer av katekolaminer vil i tillegg øke laktatproduksjonen gjennom aerob glykolyse. Den svært alvorlige hyperlaktatemien og acidosen kan igjen tenkes å ha gitt hemodynamisk/systemisk påvirkning hos denne pasienten (9.). Laktatverdier på dette nivået er forbundet med høy mortalitet, men vil naturligvis være avhengig av

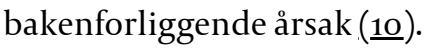

Diagnosen feokromocytomkrise er svært vanskelig å stille. Ofte vil denne bli stilt retrospektivt, som vår pasient er et eksempel på. Feokromocytomkrise er en aktuell differensialdiagnose ved hypertensiv krise, alvorlig hjertesvikt med eller uten hjerteinfarkt og arytmi samt sjokk og/eller laktacidose uten åpenbar forklaring, spesielt dersom feber foreligger samtidig (므). Slike pasienter vil ikke respondere som forventet på standard behandling. Et eksempel på dette kan være administrering av labetalol ved hypertensjon, som vil kunne forverre tilstanden. Diagnostikken inkluderer måling av metanefriner i plasma, men ved akutt krise må behandling startes før svar foreligger. Ved akutt, alvorlig sykdom vil det være høy risiko for falskt positivt svar, da referanseområdet bygger på funn hos pasienter i hvilesituasjon. I akutte krisesituasjoner forventes svært høye verdier, som vår pasient hadde. Etter å ha fått bekreftet forhøyede nivåer av metanefriner, vil normalt sett neste steg i diagnostikken av feokromocytom være CT av binyrer. Ved mistanke om krise må CT tas før svar på blodprøver foreligger.

Behandlingen vil være avhengig av hvilke manifestasjoner som foreligger, men intravenøs væske er alltid viktig uavhengig av blodtrykk. Årsaken til dette er at pasienten har vasokonstriksjon og intravasal hypovolemi. Oftest vil klinisk hypovolemi ikke være til stede initialt, men manifestere seg etter at man har startet blodtrykksbehandling, som kan gi vasodilatasjon (7.). 
Viktigste tiltak er ellers oppstart av alfablokade for å reversere vasokonstriksjon og hypertensjon samt forebygge arytmi ( $\underline{6})$. Alfablokker gis rutinemessig før kirurgisk behandling av feokromocytom. Man kan enten gi den uselektive alfablokkeren fenoksybenzamin (Dibenzyran), alternativt kan doksazosin (Carduran) benyttes. Ved akutt hypertensiv krise med behov for rask blodtrykkskontroll vil intravenøs behandling være indisert. Det finnes en alfablokker som er tilgjengelig for intravenøs administrering i Norge, fentolamin (Regitin). Dersom man ikke får tak i dette preparatet eller det er behov for tilleggsbehandling, er infusjon av nitroglyserin eller nitroprussid gode alternativer.

Kalsiumblokker kan også benyttes. Bruk av betablokker bør avventes til pasienten er adekvat alfablokkert og væskeresuscitert. Rasjonalet bak dette er at katekolaminer også stimulerer beta-2-reseptoren som gir vasodilatasjon. Ved bruk av betablokker vil denne effekten forsvinne samtidig som man får økt stimulering av alfareseptorene, med økt vasokonstriksjon og forverring av hypertensjon til følge. Ved behov for å gi betablokker i en akutt situasjon før adekvat alfablokade er oppnådd, er intravenøs esmolol, som har kort virketid, et alternativ.

Magnesiumsulfat har også vært brukt i behandlingen av feokromocytomkrise, fordi det både gir vasodilatasjon og virker arytmiprotektivt. Ved hypotensjon/sjokk som presentasjon er behandlingen mer krevende, men væskeresuscitering kommer alltid først. Vasopressorbehandling kan paradoksalt nok bli nødvendig. Det finnes ingen anbefaling om foretrukket vasopressor. Det foreligger også flere kasuistikker der det er brukt mekanisk sirkulasjonsstøtte (ECMO) i denne sammenheng (11-13).

Den endelige behandlingen er kirurgisk, men hvis mulig bør pasienten stabiliseres medikamentelt først (14). I litteraturen finner man ingen konkret anbefaling om hvor raskt pasienten bør opereres. I noen tilfeller vil det være indisert med akutt kirurgi på vital indikasjon.

Mortaliteten ved feokromocytomkrise er høy, sannsynligvis rundt 15-30 \%, avhengig av hvordan tilstanden defineres (므). Vår pasient fikk dessuten akutt kirurgi med laparotomi uten adekvat forbehandling, som også er forbundet med høy risiko. Hos pasienter med tilfeldig påvist binyretumor som skal gjennomgå elektiv kirurgi, må metanefriner kartlegges og feokromocytom utelukkes preoperativt.

Kriser i endokrinologien er sjeldne, men viktige differensialdiagnoser til komplekse indremedisinske problemstillinger. Dersom hele det kliniske bildet ikke kan forklares av funn i utredningen, er det viktig at man fortsetter jakten etter en årsakssammenheng.

Pasienten har gitt samtykke til at artikkelen blir publisert.

Artikkelen er fagfellevurdert.

\section{LITTERATUR}

1. Kimmoun A, Novy E, Auchet T et al. Erratum to: Hemodynamic consequences of severe lactic acidosis in shock states: from bench to bedside. Crit Care 2017; 21: 40. [PubMed][CrossRef]

2. Smolinske SC, Hall AH, Vandenberg SA et al. Toxic effects of nonsteroidal anti-inflammatory drugs in overdose. An overview of recent evidence on clinical effects and dose-response relationships. Drug Saf 1990; 5: 252-74. [PubMed][CrossRef]

3. Lim AKH. Abnormal liver function tests associated with severe rhabdomyolysis. World J Gastroenterol 2020; 26:1020-8. [PubMed][CrossRef]

4. Lenders JW, Duh QY, Eisenhofer G et al. Pheochromocytoma and paraganglioma: an endocrine society clinical practice guideline. J Clin Endocrinol Metab 2014; 99: 1915-42. [PubMed][CrossRef]

5. Berends AMA, Buitenwerf E, de Krijger RR et al. Incidence of pheochromocytoma and sympathetic paraganglioma in the Netherlands: A nationwide study and systematic review. Eur J Intern Med 2018; 51: 68-73. [PubMed][CrossRef] 
6. Brouwers FM, Eisenhofer G, Lenders JW et al. Emergencies caused by pheochromocytoma, neuroblastoma, or ganglioneuroma. Endocrinol Metab Clin North Am 2006; 35: 699-724, viii. [PubMed][CrossRef]

7. Whitelaw BC, Prague JK, Mustafa OG et al. Phaeochromocytoma [corrected] crisis. Clin Endocrinol (Oxf) 2014; 80: 13-22. [PubMed][CrossRef]

8. Kang JM, Lee WJ, Kim WB et al. Systemic inflammatory syndrome and hepatic inflammatory cell infiltration caused by an interleukin-6 producing pheochromocytoma. Endocr J 2005; 52: 193-8. [PubMed][CrossRef]

9. Kraut JA, Madias NE. Lactic acidosis. N Engl J Med 2014; 371: 2309-19. [PubMed][CrossRef]

10. Nichol AD, Egi M, Pettila V et al. Relative hyperlactatemia and hospital mortality in critically ill patients: a retrospective multi-centre study. Crit Care 2010; 14: R25. [PubMed][CrossRef]

11. Chao A, Yeh YC, Yen TS et al. Phaeochromocytoma crisis-a rare indication for extracorporeal membrane oxygenation. Anaesthesia 2008; 63: 86-8. [PubMed][CrossRef]

12. Sojod G, Diana M, Wall J et al. Successful extracorporeal membrane oxygenation treatment for pheochromocytoma-induced acute cardiac failure. Am J Emerg Med 2012;30: 1017.e1-3. [PubMed] [CrossRef]

13. Banfi C, Juthier F, Ennezat PV et al. Central extracorporeal life support in pheochromocytoma crisis. Ann Thorac Surg 2012; 93: 1303-5. [PubMed][CrossRef]

14. Scholten A, Cisco RM, Vriens MR et al. Pheochromocytoma crisis is not a surgical emergency. J Clin Endocrinol Metab 2013; 98: 581-91. [PubMed][CrossRef]

Publisert: 27. april 2021. Tidsskr Nor Legeforen. DOI: 10.4045/tidsskr.20.0669

Mottatt 24.8.2020, første revisjon innsendt 3.11.2020, godkjent 22.12.2020.

Publisert under åpen tilgang CC BY-ND. Lastet ned fra tidsskriftet.no 26. april 2023. 